for the formation of the coastal lagoons in south-east Australia; this work suffers from a certain diffuseness, and it may be, as E. C. F. Bird has himself said, that an attempt at this kind of essay is a little premature in the present state of knowledge. The second of these cssays, on the coral reefs of the Australian region by $\mathbf{R}$. W. Fairbridge, is in many ways the most brilliant in the book. Professor Fairbridge's knowlcdge of coral reefs and of coral limestones is unrivalled, and his application of this to the Australian recfs makes interesting and instructive reading.

Because all seventeen essays are by different people they are in varied styles, but this does not impede the reader greatly. But like "American English", "Australian English" is now written by peoplo whose original language was not English; this leads to much writing in the passive rather than in an active sense, and occasionally to somewhat obscurely written passages like those contained in the interesting work by M. J. Bik on the morpho-climatic zonation in the central highlands of New Guinea.

This collection of essays brings together scientists of many different diseiplines-geomorphologists, geologists and pedologists all make contributions. In particular, much of the work on Australian landforms stems from the resource surveys of the CSIRO Division of Land Research, illustrating how applied geomorphology has helped the work of the more academic side of the subject and also how Australia has applied landform knowledge to practical ends.

The volume shows signs of having been edited hastily, for there is a long list of corrigenda both to the text and to the diagrams. It was probably better, however, to get the work published rather than delay it too long. It is well illustrated by thirty-six pages of half-tones, each essay containing at least one of them. The diagrams are plentiful and on the whole uniformly drawn. It would have been helpful to have had some of the maps on folding sheets, so that they could be referred to more casily when reading the text.

The book marks a distinct stage and a great development in the knowledge of Australian landforms. It not only introduces the results of new work, but the many references will make the problems of Australian landforms much more familiar to all students of the subject.

M. M. Sweeting

\section{PROTEIN MODELS}

\section{Poly- $\alpha$-Amino Acids}

Protein Models for Conformational Studies. Edited by (Kerald D. Fasman. (Biological Macromolecules: a Series of Monographs.) Pp. xv +764 . (London: Edward Arnold (Publishers), Ltd.; New York: Marcel Dekker, lnc., 1967.) $275 s$.

OCCASIONALIY on examining edited books of review or general research articles by, as this dust-cover proclaims, leading authorities, I find that either the authorities are far from leading their fields or they are almost unknown. It is probably the first duty of an editor of such a volume to ensure that the writers are known and respected in their various fields of activity, and in assembling the contributors to this volume Dr Fasman has successfully discharged this duty.

This is the first edited volume of a series on biological macromolecules, the purpose of which, according to the introduction, is a "periodic presentation of critical evaluations of various aspects of a general field". In this case the general field being evaluated concerns the application of physico-chemical techniques to conformational studies of poly- $\alpha$-amino-acids. Of the thirteen articles presented, one by Silman and Sela on the "Biological Properties of Poly- $\alpha$-Amino Acids" falls outside the general scope of the volume but nevertholess gives a full and interesting account of the use of synthetic polypeptides in studies of such topics as the action of proteolytic enzymes, the molecular basis of immunogenicity and antigenic specificity and the interaction of poly- $\alpha$-aminoacids with biological macromolecular systems such as nucleic acids, proteins, viruses and bacteria. Nine of the other twelve articles are by specialists in the various techniques used; one by Mandelkern is a review of the physical studies of poly-x-proline and the remaining two articles aro concerned with the factors involved in the conformations and stabilitics of polypeptide chains. Both of the last two articles are very long, about 100 pages; the one by Poland and Sheraga is theoretical and applies statistical mechanics to conformational analysis, discussing in particular the non-covalent factors involved in the determination of polypeptide conformations and also the mechanics of the helix $\rightarrow$ coil transition. The article by Fasman is an exhaustive review of the considerable body of experimental data, as attested by the 457 references quotcd, which now exist on the factors (for example, nature of sidechain, length of main chain and solvent system) which determine the conformation of the polypeptide backbone.

Leading research workers have contributed the articles on the specialist techniques and so it need scarcely be said that they are authoritative accounts of the current situation in the various fields. The topics covered are high angle X-ray diffraction of polypeptides (A. Elliott) and low angle diffraction of the different phases in poly peptide/solvent systems (P. Saludjian and V. Luzzati); the usual spectroscopic techniques of the infrared ( $T$. Miyazawa), ultraviolet (W. B. Gratzer), optical rotatory dispersion (J. T. Yang) and circular dichroism (S. Bey. chok) and the additional fields of light scattering and hydrodynamies (H. Benoit, L. Freund and G. Spach), hydrogen exchange (S. W. Englander) and the dielectric properties of polypeptides in solution (A. Wada). Although the preface states that the "considerable amount of exciting work" forthcoming since 1961 was responsible for the publication of this volume, not all the fields have made significant advances since then and some of them add little new to what was known in 1962. If any of these articles were to be specially mentioned, one might select that by Gratzer on ultraviolet studies of polypeptides which includes not only the basic theory, application and results but also an extremely useful section on the experimental aspects and difficulties of measurements in the far ultraviolet, and the articles by Miyazawa and Englander, who have endeavoured not to re-review work but to present a more critical account of the application of their techniques.

'There is little doubt that this volume will be a very useful source of reference to the work completcd on poly$\alpha$-amino-acids up to the beginning of 1966 . There are two criticisms: one is the usual complaint of the time delay, in this case almost two years, which has elapsed since the completion of the articles and their publication. The second criticism is the extremely high price.

\section{E. M. BRADBURY}

\section{BIOLOGICAL ULTRASTRUCTURE}

\section{Engström-Finean Biological Ultrastructure}

Second edition. By J. B. Finean. Pp. viii +384. (Now York: Academic Press, Inc.; London: Academic Press, Ine. (London), Ltd., 1967.) 120s.

I THINK it would have been wiser, despite Finean's declared attachment to it, if the book had not attempted in a section of forty-seven pages to give before the ultrastructural details themselves a summary of the methods used in their elucidation. To deal adequately in such a short compass with the principles of the operation of the 